Original article

\title{
The level of microelements and heterogeneity of joint hypermobility as an endophenotype of undifferentiated connective tissue dysplasia
}

\author{
Luiza Z. Lukmanova ${ }^{1}$, Rashit A. Davletshin ${ }^{1}$, Rita I. Khusainova ${ }^{2}$, Anton V. Tyurin ${ }^{1}$ \\ ${ }^{1}$ Bashkir State Medical University, Ufa, Russia \\ ${ }^{2}$ Institute of Biochemistry and Genetics, Ufa, Russia
}

Received 18 January 2019, Revised 18 December 2019, Accepted 18 February 2020

(C) 2019, Lukmanova L.Z., Davletshin R.A., Khusainova R.I., Tyurin A.V.

(C) 2019, Russian Open Medical Journal

Abstract: Objective - The aim of the work was to study serum concentrations of magnesium, copper, zinc, phosphorus and calcium in individuals with undifferentiated connective tissue dysplasia (UCTD) and joint hypermobility (JH) in an isolated and combined state.

Material and methods - the concentrations of magnesium, copper, zinc, phosphorus and calcium were measured by the direct colorimetric method in 55 people with joint hypermobility and in 34 - without hypermobility.

Results - There were no significant differences between serum concentrations of microelementsin groups with and without JH. In patients with mild and severe UCTD significant decrease in serum magnesium concentrations was noted $(U=2.12, p=0.034$ and $U=3.7, p=0.012)$. In patients with isolated JH significant serum zinc concentrationdecrease was revealed compared with the control group $(U=3.12, p=0.022)$. Serum magnesium concentrations were reduced in all patients with $\mathrm{UCTD}$ and JH; in the groups with isolated dysplasia and combined pathology, the differences reached the level of statistical significance $(U=2.78, p=0.024$ and $U=3.2, p=0.018)$.

Conclusion - The study revealed significant associations of a decrease in serum magnesium concentrations with the development of uCTD in an isolated and combined with JH state and decrease in serum zinc concentrations with the development of isolated JH.

Keywords: trace elements, zinc, magnesium, undifferentiated connective tissue dysplasia, joint hypermobility.

Cite as Lukmanova LZ, Davletshin RA, Khusainova RI, Tyurin AV. The level of microelements and heterogeneity of joint hypermobility as an endophenotype of undifferentiated connective tissue dysplasia. Russian Open Medical Journal 2020; 9: e0106.

Correspondence to Anton V. Tyurin. Address: Nezhinskaya str., 17, Ufa, 450064, Russia. Phone: +79273340035. E-mail: anton.bgmu@gmail.com.

\section{Introduction}

Joint hypermobility $(\mathrm{JH})$ is a condition in which the amplitude of active and / or passive movements in a joint exceeds the average norm. The first literature references date back to the $80 \mathrm{~s}$ of the 20th century. Since then, the views on the etiology and pathogenesis of $\mathrm{JH}$ have undergone a number of changes, but to date, a number of questions about classification, pathogenesis and diagnosis of $\mathrm{JH}$ are still unclear. The importance of this problem is due to the development of pain $[1,2]$ andearly degenerative pathology of the musculoskeletal system [3-5]. In the Englishlanguage literature $\mathrm{JH}$ is mainly considered like a part of monogenic forms of connective tissue dysplasia (CTD) - EhlersDanlo syndrome, Marfan syndrome, osteogenesisimperfectaand several others [6]. Russian scientists, along with these nosologies, distinguish an undifferentiated variant of connective tissue dysplasia (UCTD), which can also be associated with JH [7]. However, the presence of joint hypermobility in a number of individuals without signs of CTD leaves the questions of their connection, development andetiopathogenesis open. It is also worth remembering that an increased range of motion in the joints as a variant of the norm is possible in children and adolescents or acquired doing special exercises, during sports or some professional activities [8]. In addition to genetic markers, whose contribution to the development of CTD and JH is beyond doubt, there is an assumption about the role ofof microelementsmagnesium, zinc, copper, calcium, phosphorus - in the development of these conditions. A number of studies have been carried out, mainly related to UCTD and its individual phenotypes [9-11]. However, studies of the role of microelementsin patients with isolated joint hypermobility orhypermobility combined with uCTDhave not been conducted.

The aim of the work is to estimate serum concentrations of magnesium, copper, zinc, phosphorus and calcium in individuals with UCTD and JH in an isolated and combined state.

\section{Material and Methods}

\section{Patients's characteristics}

250 healthy individuals of young (18-25 years old) age were examined for the presence of joint hypermobility and/or UCTD, and 89 of them were included in the study. all patients signed the voluntaryinformed consent. The exclusion criteria were: systemic connective tissue diseases, secondary $\mathrm{JH}$ on the background of sports exercises or professional activities, the monogenic form of CTD, active bacterial or viral infection, traumatic injuries of joints in the anamnesis, pregnant or lactating women, refusal to participate in the study. 
Table 1. Serum concentrations of microelementsin patients with and without JH

\begin{tabular}{|c|c|c|}
\hline Parameters & Presence of $\mathrm{JH}, n=55$ & $\begin{array}{c}\text { Absence of } \mathrm{JH}, n=34 \\
\text { (control group) }\end{array}$ \\
\hline Copper, mmol/l & $\begin{array}{c}804.3(750.2,837.7) \\
p=0.792\end{array}$ & $803.5(758.2,828.2)$ \\
\hline Zinc, $\mathrm{mkmol} / \mathrm{l}$ & $\begin{array}{c}13.2(11.38,15.0) \\
p=0.875\end{array}$ & $13.2(11.38,15.5)$ \\
\hline Phosphorus, $\mathrm{mmol} / \mathrm{l}$ & $\begin{array}{c}1.19(1.06,1.28) \\
p=0.257\end{array}$ & $1.21(1.06,1.31)$ \\
\hline Magnesium, mmol/l & $\begin{array}{c}0.8(0.7,0.9) \\
p=0.890\end{array}$ & $0.8(0.7,0.9)$ \\
\hline Calcium, mmol// & $\begin{array}{c}2.2(2.13,2.3) \\
p=0.171\end{array}$ & $2.24(2.2,2.3)$ \\
\hline
\end{tabular}

p-level is for comparison with control group. Data presented as median with low and upper quartiles - Me (LQ, UQ).

Table 2. Serum concentrations of microelementsin patients with varying severity of uCTD.

\begin{tabular}{lccc}
\hline Parameters & Severe $u C T D, n=6$ & Mild $u C T D, n=48$ & $\begin{array}{c}\text { Absence of } u C T D, \\
n=35 \text { (control group) }\end{array}$ \\
\hline Copper, & $762.2(620.5,802.7)$ & $804.2(754.9,840.8)$ & $812.2(750.2,839.2)$ \\
$\mathrm{mmol} / \mathrm{l}$ & $\mathrm{p}=0.206$ & $\mathrm{p}=0.830$ & \\
\hline Zinc, & $13.2(13.2,16.39)$ & $12.75(10.9,15.0)$ & $13.6(11.38,15.48)$ \\
$\mathrm{mkmol} / \mathrm{l}$ & $\mathrm{p}=0.190$ & $\mathrm{p}=0.495$ & \\
\hline Phosphorus, & $1.06(0.9,1.14)$ & $1.2(1.07,1.31)$ & $1.18(1.06,1.25)$ \\
mmol/l & $\mathrm{p}=0.083$ & $\mathrm{p}=0.219$ & \\
\hline Magnesium, & $0.7(0.6,0.8)$ & $0.75(0.7,0.9)$ & $0.9(0.7,0.9)$ \\
mmol/l & $\mathrm{p}=0.024$ & $\mathrm{p}=0.018$ & \\
Calcium, & $2.2(2.2,2.3)$ & $2.2(2.1,2.3)$ & $2.2(2.2,2.3)$ \\
mmol/l & $\mathrm{p}=0.940$ & $\mathrm{p}=0.420$ & \\
\hline
\end{tabular}

p-level is for comparison with control group. Data presented as median with low and upper quartiles - Me (LQ, UQ).

Table 3. Serum concentrations of microelementsin patients with JH and uCTD in an isolated and comorbid state

\begin{tabular}{lcccc}
\hline Parameters & $\begin{array}{c}u C T D+J H+, \\
n=30\end{array}$ & $\begin{array}{c}u C T D+J H-, \\
n=25\end{array}$ & $\begin{array}{c}u C T D-J H+, \\
n=8\end{array}$ & $\begin{array}{c}\text { uCTD-JH-, } \\
n=26 \text { (контроль) }\end{array}$ \\
\hline Copper, & 803.9 & 815.4 & 825.75 & 787.4 \\
mmol/l & $(743.0,837.7)$ & $(735.8,853.6)$ & $(768.85,837.25)$ & $(758.2,820.2)$ \\
& $p=0.870$ & $p=0.329$ & $p=0.340$ & \\
\hline Zinc, & 13.4 & 12.3 & 11.0 & 12.97 \\
mkmol/l & $(11.38,15.6)$ & $(10.0,14.11)$ & $(10.94,14.94)$ & $(11.38,15.5)$ \\
& $p=0.890$ & $p=0.770$ & $p=0.022$ & \\
\hline Phosphorus, & 1.16 & 1.18 & 1.19 & 1.21 \\
mmol/l & $(1.01,1.25)$ & $(1.12,1.27)$ & $(1.1,1.27)$ & $(1.05,1.33)$ \\
& $p=0.160$ & $p=0.640$ & $p=0.730$ & \\
\hline Magnesium, & $0.80(0.7,0.8)$ & $0.75(0.7,0.8)$ & $0.85(0.8,0.95)$ & $0.9(0.7,0.9)$ \\
mmol/l & $p=0.031$ & $p=0.033$ & $p=0.144$ & \\
\hdashline Calcium, & $2.2(2.1,2.3)$ & $2.2(2.1,2.3)$ & $2.25(2.2,2.3)$ & $2.24(2.2,2.3)$ \\
mmol/l & $p=0.220$ & $p=0.910$ & $p=0.170$ & \\
\hline
\end{tabular}

"+" presence of a sign, "_" absence of a sign. p-level is indicated for comparison with the control group. Data presented as median with low and upper quartiles - Me (LQ, UQ).

\section{Study design}

A case-control study was conducted in three stages.

At the first stage, the presence of JHwas evaluated without presence of UCTD using Beighton criteria [12]. The following tests were carried out:

i) Passive extension of the little finger of the brush more than $90^{\circ}$ (right hand and left hand)

ii) Passive pressing of the thumb of the hand to the inner side of the forearm (right hand and left hand). iii) Re-extension in the elbow joint of more than $10^{\circ}$ (right hand and left hand).

iv) Re-extension in the knee joint of more than $10^{\circ}$ (right leg and left leg).

v) Front torso with palms touching the floor with straight legs.

For each positive test, 1 point was assigned, the maximum possible number of points -9 , a positive result - the sum of points from 4 inclusive and higher. Among the examined individuals, 55 people were identified; the comparison group consisted of 34 people without $\mathrm{JH}$.

At the second stage, the presence of UCTD was evaluated without presence of $\mathrm{JH}$ using the diagnostic algorithm according to T.I. Kadurina in the authorsmodification $[13,14]$. This algorithm is a series of phenotypic characters with a diagnostic value assigned to each one in points. After examining and filling out the appropriate questionnaire, a summation is made and the conclusion on the presence of UCTD is formed by the total of points: from 8 to 16 points - mild UCTD, more than 17 points severe UCTD. Among the examined individuals, 54 people with uCTDwere identified, among them mild - in 48 people, severe - in 6 people. The comparison group consisted of 35 people without uCTD.

At the third stage, the combined and isolated availability of $\mathrm{JH}$ and UCTDwas assessed. A combination of pathologies was detected in 30 people, isolated JH - in 25 people, isolated UCTD in 8 people. The comparison group consisted of 26 people without $\mathrm{JH}$ and $\mathrm{UCTD}$.

\section{Microelement levels measurement}

The serum concentrations of copper $(\mathrm{mmol} / \mathrm{L})$, zinc $(\mu \mathrm{mol} / \mathrm{L})$, phosphorus ( $\mathrm{mmol} / \mathrm{L})$, magnesium $(\mathrm{mmol} / \mathrm{L})$ and calcium $(\mathrm{mmol} / \mathrm{L})$ were determined In all the formed groupsby direct colorimetric method on a BioChem360 (USA) using diagnostic kits from Hospitex (Russia), Cobas (Japan).

\section{Statistic alanalysis}

For statistical data processing, the software packages MSOfficeExcel 2007 (Microsoft, USA), Statistica v.6.2 (StatSoft, USA) were used. The calculation of the median (Me) and the interquartile range (LQ, UQ) was used. The normality of the distribution of quantitative indicators was checked using the Shapiro-Wilk criterion, an intergroup comparison of the obtained data was carried out taking into account the volume and normality of the data distribution using the nonparametric Mann-Whitney criterion (U). In all cases the result considered statistically significant at $p<0.05$

\section{Results}

We estimate serum concentrations of copper, zinc, phosphorus, magnesium and calcium in individuals with $\mathrm{JH}$ and without it, regardless of the presence of UCTD. The results are presented in Table 1. There were no statistically significant differences between serum concentrations of microelementsin the studied groups. This fact can be explained by the heterogeneity of $\mathrm{JH}$ and various etiological factors underlying it.

Similar examination was conducted in individuals with the presence and absence of UCTD of varying severity. The results are 
presented in Table 2 . In patients with mild and severe UCTD, a statistically significant decrease in serum magnesium concentrations was observed $(U=2.12, p=0.034$ and $U=3.7$, $p=0.012$, respectively) compared with a group of individuals without UCTD. The serum concentration of copper decreased according to severity of dysplasia, but the differences did not reach the level of statistical significance. Serum concentrations of zinc, phosphorus and calcium in the studied groups did not differ significantly.

To differentially assess the involvement of microelementsin the development of $\mathrm{JH}$ and UCTD, their concentrations were measured in groups with isolated and combined variants of connective tissue dysplasia and joint hypermobility. The results are presented in Table 3. Serum zinc concentration in patients with isolated $\mathrm{JH}$ was significantly revealed compared with the control group $(U=3.12, p=0.022)$. Serum zinc concentrations were comparable in patients with isolated UCTD and combined pathology to those in the control group. Serum magnesium concentrations were significaly reduced in groups with isolated dysplasia and combined pathology relative to the control group $(U=2.78, p=0.024$ and $U=3.2, p=0.018$, respectively). Copper concentrations were generally lower in patients with pathology of the connective tissue, compared with the control group, the differences were trend-like. There were no differences in serum concentrations of phosphorus and calcium in the studied groups.

\section{Discussion}

According to current data, magnesium is the second most important trace element after sodium. It takes part in more than 600 enzymatic processes of the human body [14]. The value of magnesium in the functioning of the connective tissue system and its derivatives was also studied. Bones loses its quality characteristics according to reduced concentrations of this trace element, which leads to the development of osteoporosis [15]. In a long-term prospective study, which included 2,245 men aged 42 to 61 years, an association of decreased serum magnesium concentration with fractures of the peripheral skeleton was revealed [16]. In a study of chondrocalcinosis in the Chinese population, Zeng et al. found that patients with lower serum magnesium levels, even within the normal range, had a higher prevalence of chondrocalcinosis of knee [17]. This can by explained by magnesium effect on the calcium and vitamin $D$ metabolism, which play a significant role in the connective tissue metabolism in general [18]. A histological examination of biopsy specimens of the enlarged thoracic aorta in patients with UCTD revealed a decrease in magnesium level, while zinc and copper levels were close to normal [19]. The role of magnesium in the activation of anabolic processes of connective tissue was proved by a group of Swedish scientists who found that titanium coated bone prostheses containing this microelement enhanced bone formation and increased levels of anabolic process markers in the perioperative zone in experimental animals [20]. According to the results of our research, a decrease in the serum magnesium concentration is associated with the presence of JH and UCTD.

The influence of other microelementson the structure and function of connective tissue is less studied. Copper is a cofactor in the collagen and elastin synthesis, which form the structural basis of connective tissue [21, 22] and, along with nickel, is more concentrated in cartilage and tendons than in bone tissue [23]. Increased daily intake of phosphorus can lead to a disturbance of calcium balance and, as a consequence, metabolic processes in the bone with the development of osteopenia [24]. Zinc deficiency and molecular disorders of its transporter genes are associated with the development of a number of skin diseases, such as alopecia, prolonged wounds healing, pellagra and several others. In addition, a mutation in the ZIP13 transporter gene causes the phenomenon of hyperelasticity of the skin and hypermobility of small joints, which is characteristic of Ehlers-Danlo syndrome [25]. Studying experimental osteoarthritis on mutant cell lines of chondrosarcoma SW1353 and model animals, it was found that increasing of zinc concentration in cell culture or adding it to the diet of rats reduces general oxidative stress, secretion of interleukin $1 \mathrm{~b}$, interleukin 13 and matrix metalloproteinase 13, thereby reducing the risk of osteoarthritis [26]. Studying the levels of microelementsin patients with rheumatic diseases, a decrease in zinc concentration was revealed only in osteoarthritis, magnesium concentration was reduced in osteoarthritis, rheumatoid arthritis, copper concentration was elevated in psoriatic arthritis [27]. According to the results of our research, a reduced concentration of zinc is associated with isolated $\mathrm{JH}$.

Studies of magnesium, phosphorus and calcium concentrations in children 6-17 years old with signs of connective tissue dysplasia showed a significant decrease in serum calcium concentration, magnesium concentration was tended to decrease, phosphorus concentrations did not differ from those in the control group [28]. A tendency to the copper concentration decrease in the with UCTD was observed, not reaching the level of statistical significance. Concentrations of phosphorus and calcium in the studied groups did not differ from control group.

Thus, the results revealed associations between the serum concentrations of a number of microelementsand the presence of joint hypermobility and UCTD, which makes medical and nutritional correction possible.

\section{Conclusion}

A decrease in serum magnesium concentrations with the development of UCTD in an isolated and combined with $\mathrm{JH}$ state and a decrease in circulating zinc concentrations is significantly associated with the development of isolated $\mathrm{JH}$.

\section{Study Limitations}

The main limitations of the study were the sample size, which had the ability to conduct biochemical diagnostics, which limited the possibility of using multivariate analysis methods, as well as the inability to compare the concentrations of microelementsin various body fluids and derivatives (skin, nails, hair), for a more comprehensive analysis of their content.

\section{Ethical approval}

All procedures involved in human studies comply with the ethical standards of the institutional and national research committee and the 1964 Helsinki Declaration and its later amendments or comparable ethical standards.

\section{Acknowledgments}

The reported study was funded by RFBR, project № 17-44-020913 p_a.

\section{Conflict of interest}

The authors declare no conflict of interest. 


\section{References}

1. Wolf JM, Cameron KL, Owens BD. Impact of joint laxity and hypermobility on the musculoskeletal system. J Am Acad Orthop Surg 2011; 19(8): 463-471. https://doi.org/10.5435/00124635-20110800000002.

2. Tikhomirova NY, Eliseeva LN, Porubayko LN, Malkhasyan IG. Phenotypic characteristics young people with articular pain syndrome. Modern science success 2016; 10(11): 6-9. Russian. https://elibrary.ru/item.asp?id=27540953.

3. Jónsson $H$, Valtýsdóttir ST. Hypermobility features in patients with hand osteoarthritis. Osteoarthritis Cartilage 1995; 3(1): 1-5. https://doi.org/10.1016/s1063-4584(05)80032-9.

4. Gürer G, Bozbas GT, Tuncer T, Unubol Al, Ucar UG, Memetoglu OI. Frequency of joint hypermobility in Turkish patients with knee osteoarthritis: a cross sectional multicenter study. Int J Rheum Dis 2018; 21(10): 1787-1792. https://doi.org/10.1111/1756-185X.12883.

5. Viktorova IA, Konshu NV, Ivanova DS. Osteoarthritis at patients with hypermobility of joints: family studies. Medical News of North Caucasus 2016; 11(2.2): 305-308. Russian. https://doi.org/10.14300/mnnc.2016.11062.

6. Castori M, Colombi M. Generalized joint hypermobility, joint hypermobility syndrome and Ehlers-Danlos syndrome, hypermobility type. Am J Med Genet C Semin Med Genet 2015; 169C(1): 1-5. https://doi.org/10.1002/ajmg.c.31432.

7. Martynov AI, Nechaeva GI, Vershinina MV, Delov RA, Drokina OV, Druk IV, et al. Guidelines of the Russian Scientific Medical Society of Internal Medicine on the diagnosis, treatment and rehabilitation of patients with the connective tissue displasia (first edition). Medical News of North Caucasus 2018; 13(1-2): 137-209. Russian. https://doi.org/10.14300/mnnc.2018.13037.

8. Khmelevskaya IG, Matvienko EV. Clinical manifestations of teenager's hypermobility syndrome. In: Age-related and gender peculiarities of health and illness. A collection of materials of the International Scientific and Practical Conference. N.K. Gorshunova ed. Kursk, Russia, 2016: 412-419. Russian. https://elibrary.ru/item.asp?id=26200731\&.

9. Nechaeva GI, Drokina OV, Druk IV, Vershinia MV, Lialiukova EA, Kolmenkova IV. Main approaches in treatment of patients with connecting tissues dysplasia. Lechashhiy Vrach 2014; (8): 70. Russian. https://elibrary.ru/item.asp?id=21856335.

10. Tvorogova TM, Vorobyova AS. Undifferentiated connective tissue dysplasia from the position of diselementosis in children and adolescents. Russian Medical Journal 2012; 20(24): 1215-1221. Russian. https://elibrary.ru/item.asp?id=18419253.

11. Amoozgar $H$, Rafizadeh $H$, Ajami G, Borzoee $M$. The prevalence of hypomagnesaemia in pediatric patients with mitral valve prolapse syndrome and the effect of $\mathrm{mg}$ therapy. Int Cardiovasc Res J 2012; 6(3): 92-95. https://www.ncbi.nlm.nih.gov/pubmed/24757600.

12. Beighton $\mathrm{P}$, Solomon $\mathrm{L}$, Soskolne $\mathrm{CL}$. Articular mobility in an African population. Ann Rheum Dis 1973; 32(5): 413-418. https://doi.org/10.1136/ard.32.5.413.

13. Kadurina TI, Gorbunova VN. Connective tissue dysplasia: a guide for doctors. Moscow, Russia: ELBI-SPb, 2009; 704 p. Russian.

14. de Baaij JH, Hoenderop JG, Bindels RJ. Magnesium in man: implications for health and disease. Physiol Rev 2015; 95(1): 1-46. https://doi.org/10.1152/physrev.00012.2014.

15. Castiglioni S, Cazzaniga A, Albisetti W, Maier JA. Magnesium and osteoporosis: current state of knowledge and future research directions. Nutrients 2013; 5(8): 3022-3033. https://doi.org/10.3390/nu5083022.

16. Kunutsor SK, Whitehouse MR, Blom AW, Laukkanen JA. Low serum magnesium levels are associated with increased risk of fractures: a long-term prospective cohort study. Eur J Epidemiol 2017; 32(7): 593603. https://doi.org/10.1007/s10654-017-0242-2.

17. Zeng C, Wei J, Terkeltaub R, Yang T1, Choi HK, Wang YL, et al. Doseresponse relationship between lower serum magnesium level and higher prevalence of knee chondrocalcinosis. Arthritis Res Ther 2017; 19(1): 236. https://doi.org/10.1186/s13075-017-1450-6.

18. Rosanoff A, Dai $Q$, Shapses SA. Essential nutrient interactions: does low or suboptimal magnesium status interact with vitamin $D$ and/or calcium status? Adv Nutr 2016; 7(1): 25-43. https://doi.org/10.3945/an.115.008631.

19. Okuneva GN, Karaskov AM, Cherniavsky AM, Volkov AM, Trunova VA, Zvereva VV. Participating of chemical elements in connective tissue dysplasia at the aortic aneurysm. Patologiya Krovoobrashcheniya Kardiokhirurgiya 2009; (4): 28-31. Russian. https://elibrary.ru/item.asp?id=14776805.

20. Galli S, Stocchero M, Andersson M, Karlsson J, He W, Lilin T. The effect of magnesium on early osseointegration in osteoporotic bone: a histological and gene expression investigation. Osteoporos Int 2017 28(7): 2195-2205. https://doi.org/10.1007/s00198-017-4004-5.

21. O'Dell BL. Roles for iron and copper in connective tissue biosynthesis. Philos Trans $R$ Soc Lond B Biol Sci 1981; 294(1071): 91-104. https://doi.org/10.1098/rstb.1981.0091.

22. Scheiber I, Dringen R, Mercer JF. Copper: effects of deficiency and overload. Met lons Life Sci 2013; 13: 359-387. https://doi.org/10.1007/978-94-007-7500-8 11.

23. Roczniak W, Brodziak-Dopierała B, Cipora E, Jakóbik-Kolon A, Kluczka J, Babuśka-Roczniak M. Factors that Affect the content of cadmium, nickel, copper and zinc in tissues of the knee joint. Biol Trace Elem Res 2017, 178(2): 201-209. https://doi.org/10.1007/s12011-016-0927-5.

24. Takeda E, Yamamoto H, Yamanaka-Okumura H, Taketani Y. Increasing Dietary Phosphorus Intake from Food Additives: Potential for Negative Impact on Bone Health. Adv Nutr 2014; 5(1): 92-97. https://doi.org/10.3945/an.113.004002.

25. Ogawa $Y$, Kinoshita M, Shimada S, Kawamura T. Zinc and skin disorders. Nutrients 2018; 10(2): E199. https://doi.org/10.3390/nu10020199.

26. Huang TC, Chang WT, Hu YC, Hsieh BS, Cheng HL, Yen JH, et al. Zinc protects articular chondrocytes through changes in Nrf2-mediated antioxidants, cytokines and matrix metalloproteinases. Nutrients 2018 ; 10(4). pii: E471. https://doi.org/10.3390/nu10040471.

27. Syniachenko OV, Geiko IA, Sokrut OP, Hapchenkova DS, Perepada AV. Clinical and pathogenetic significance of osteoassociated microelements in the joint diseases. Report I. Microelementosis in the Blood. Pain, Joints, Spine 2016; (2): 34-40. Russian. https://elibrary.ru/item.asp?id=26462802.

28. Lebed'kova SE, Sumenko VV, Cherkasova EV, Trusova OYu, Klimova AR. The indicators of mineral metabolism in children and adolescents with dysplasia of connective tissue. Treatment and Prevention 2015; (1): 34 37. Russian. https://elibrary.ru/item.asp?id=23576676.

\section{Authors:}

Luiza Z. Lukmanova - MD, Postgraduate, Department of Hospital Therapy, Bashkir State Medical University, Ufa, Russia. http://orcid.org/0000-00032061-4969.

Rashit A. Davletshin - MD, DSc, Professor, Department of Hospital Therapy, Bashkir State Medical University, Ufa, Russia. http://orcid.org/0000-0001-9520-3801.

Rita I. Khusainova - DSc, Leading Researcher, Laboratory of Biochemistry and Genetics, Institute of Biochemistry and Genetics, Academy of Sciences of the Republic of Bashkortostan, Ufa, Russia. http://orcid.org/0000-00028643-850X

Anton V. Tyurin - MD, PhD, Associate Professor, Department of Internal medicine, Bashkir State Medical University, Ufa, Russia. http://orcid.org/0000-0002-0841-3024 